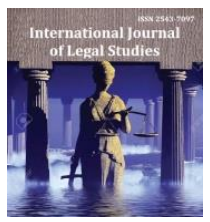

Received: 30 May 2018 Revised: 20 June 2018 Accepted: 20 June 2018 Published: 30 June 2018

\section{OCHRONA PORZĄDKU I BEZPIECZEŃSTWA \\ PUBLICZNEGO W USTAWODAWSTWIE WOLNEGO MIASTA KRAKOWA 1815-1846}

\author{
PROTECTION OF PUBLIC ORDER \\ AND SAFETY IN THE LEGISLATION \\ OF THE FREE CITY OF CRACOW 1815-1846
}

\author{
Pawel Cichoń \\ Dr hab.; Faculty of Law and Administration, \\ Jagiellonian University in Krakow, Poland \\ *Corresponding author: e-mail: pawel.cichon@uj.edu.pl
}

\title{
Streszczenie
}

Celem artykułu jest omówienie najważniejszych regulacji prawnych obowiązujących w Wolnym Mieście Krakowie, które dotyczyły ochrony porządku i bezpieczeństwa publicznego. Były to akty prawne dotyczące zwalczania żebractwa, włóczęgostwa, polityki paszportowej, ewidencji ludności, ochrony interesów i praw konsumentów, dbania o bezpieczeństwo budowlane, sanitarne, przeciwpożarowe, o utrzymanie spokoju, czystości i porządku w Krakowie oraz związane ze zwalczaniem przestępczości. Wykonywaniem zadań służących ochronie porządku i bezpieczeństwa publicznego zajmowały się organy policyjne i administracyjne.

Słowa kluczowe: Policja, administracja, Wolne Miasto Kraków

\begin{abstract}
The goal of this article is to discuss the most important legal regulations in the Free City of Cracow concerning the protection of public order and public safety. These were legal acts fighting against crime, vagabonding, and begging, as well as for regulating passport policy, population registration, protection of interests and consumer rights, building safety, sanitary and fire protection, maintaining peace, tidiness and order in Cracow. Police and administrative authorities were responsible for carrying out public security and public security tasks.
\end{abstract}

Keywords: Police, administration, the Free City of Cracow

(C) 2018 /Published by: Międzynarodowy Instytut Innowacji Nauka-Edukacja-Rozwój w Warszawie, Polska

This is an open access article under the CC BY-NC license

(http://creativecommons.org/licenses/by-nc/4.0/)

Cichoń P. (2018). Protection of Public Order and Safety in The Legislation

of The Free City of Cracow 1815-1846. International Journal of Legal Studies, 1(3)2018; 337-357

DOI 10.5604/01.3001.0012.2183 


\section{Wprowadzenie}

Zagadnienia dotyczące ochrony porządku i bezpieczeństwa publicznego w Wolnym Mieście Krakowie (Rzeczypospolitej Krakowskiej) występowały w aktach normatywnych różnej rangi. Wiązało się to z faktem, że ochrona tych wartości stanowiła i nadal stanowi jedno z najważniejszych zadań każdego państwa. Zakres zadań związanych $\mathrm{z}$ zabezpieczeniem porządku i bezpieczeństwa publicznego był bardzo szeroki i wiązał się głównie z funkcją reglamentacyjno-porządkową, którą realizowały różnego typu organy administracji państwowej. Na płaszczyźnie formalnej granice tej ochrony zakreślały przepisy prawa wskazujące, które organy i w jakich sytuacjach mogły podejmować władcze ingerencje $\mathrm{w}$ tym ograniczające prawa i wolności jednostki. Prawo regulowało też obszary życia społecznego, które podlegały szczegółowej reglamentacji prawnej. $Z$ kolei społeczna i polityczna rola porządku i bezpieczeństwa publicznego powodowała, że wydawane przepisy miały charakter celowościowy i zmierzały do eliminowania zagrożeń oraz zapewnienia niezakłóconego funkcjonowania społeczeństwa jak również ustalonego porządku prawnego.

W Wolnym Mieście Krakowie nie było definicji legalnej pojęć „porządek publiczny” i „bezpieczeństwo publiczne”. Pojęcia te wyznaczały bliżej nieokreślone zadania władz Wolnego Miasta Krakowa oraz stanowiły kryterium prawne ich działania, zwłaszcza organów policyjnych. Oba pojęcie należały i nadal należą do tzw. pojęć nieoznaczonych, wyrażeń nieostrych, których ramy znaczeniowe są bardzo rozciągliwe. Dzięki temu ich użycie pozwalało na elastyczność i adekwatne dostosowywanie ich treści do zmieniającej się sytuacji wewnętrznej w kraju, w tym zwłaszcza sytuacji politycznej. Z drugiej strony pozwalało to na względną stabilność obowiązującego prawa. W Wolnym Mieście Krakowie pojęcie „bezpieczeństwo” występowało jeszcze w innym kontekście, mianowicie jako „bezpieczeństwo państwa”. Była to szersza kategoria niż „,bezpieczeństwo powszechne”, a kompetencje w tym obszarze należały bezpośrednio do prezesa Senatu Rządzącego, który realizował w tym zakresie tzw. policję wyższą. $Z$ tego tytułu sprawował on zwierzchnictwo nad Dyrekcją Policji, miał też prawo wydawać jej wiążące polecenia i rozkazy oraz kon-

(C) 2018 /Published by: Międzynarodowy Instytut Innowacji Nauka-Edukacja-Rozwój w Warszawie, Polska

This is an open access article under the CC BY-NC license

(http://creativecommons.org/licenses/by-nc/4.0/)

Cichoń P. (2018). Protection of Public Order and Safety in The Legislation of The Free City of Cracow 1815-1846. International Journal of Legal Studies, 1(3)2018; 337-357

DOI 10.5604/01.3001.0012.2183 
trolować ich wykonanie. Analogiczne uprawnienia posiadał wobec komendanta milicji, gdyż prezes Senatu był jednocześnie najwyższym zwierzchnikiem lokalnych sił zbrojnych. Na dodatek miał on prawo utrzymywać regularne kontakty z rezydentami mocarstw opiekuńczych, szczególnie w sprawach „konfidencjonalnych” [(Wachholz Sz., 1957, s. 207-216, 222-232) (Cichoń P., 2014, s. 40-41)].

Warto podkreślić, że źródłami prawa obowiązującymi w Wolnym Mieście Krakowie były nie tylko akty prawne wydawane przez miejscowe organy, tj. Senat pełniący funkcję rządu, czy też Zgromadzenie Reprezentantów, któremu powierzono rolę parlamentu [(Wachholz Sz., 1957, s. 156-157)( Bartel W. M., 1976, s.15-17)]. Fundamentalne znaczenie dla bytu prawnego tego państwa miał akt wydany na kongresie wiedeńskim, zwany traktatem dodatkowym z dnia 3 maja 1815 r., w którym państwa-sygnatariusze (Austria, Prusy i Rosja) powołali do życia właśnie „Wolne, Niepodległe i Ściśle Neutralne Miasta Kraków wraz z Okręgiem”. Zgodnie z postanowieniami kongresu wiedeńskiego, pozostawało ono pod protekcją ww. mocarstw opiekuńczych. Państwa te były osobiście zainteresowane stabilną sytuacją na terenie tego kraju, a więc skuteczna ochrona porządku i bezpieczeństwa publicznego na tym obszarze nie była tylko sprawą wewnętrzną. Zgodnie z art. 6 ww. traktatu, władze Wolnego Miasta zobowiązano do nieudzielania schronienia ani opieki zbiegom, dezerterom oraz osobom poszukiwanym, a należącym do któregoś z państwsygnatariuszy tej umowy oraz do wydawania takich osób na żądanie stosownych władz. Lokalne władze miały także aresztować tego rodzaju osoby i pod eskortą dostarczać je do granicy w celu przekazania ich właściwej straży sąsiedniego państwa (Kallas M., Krzymkowski M., 2006, s. 174-178).

Znaczenie ustrojowe dla organizacji władz Wolnego Miasta Krakowa i ich kompetencji miały akty konstytucyjne wydawane wspólnie przez mocarstwa opiekuńcze. Jednakże kwestie ochrony porządku i bezpieczeństwa publicznego w tych konstytucjach początkowo nominalnie zajmowały marginalne znaczenie. Jedynie artykuł 22 w konstytucji z 3 maja 1815 r. (Kallas M., Krzymkowski M., 2006, s. 179182) oraz w konstytucji z 11 września 1818 r. (Kallas M., Krzymkowski M., 2006, s. 183-190). wskazywał na charakter zadań milicji municypalnej, która stanowiła „służbę bezpieczeństwa wewnętrznego i policji”. Natomiast do zabezpieczenia dróg

(C) 2018 /Published by: Międzynarodowy Instytut Innowacji Nauka-Edukacja-Rozwój w Warszawie, Polska

This is an open access article under the CC BY-NC license (http://creativecommons.org/licenses/by-nc/4.0/) 
oraz terenów wiejskich powołano żandarmerię konną. Dopiero w konstytucji z 30 maja 1833 r. oprócz analogicznego zapisu określającego zadania milicji i żandarmerii (art. 26), wprowadzono nowy art. 2. Wyraźnie w nim zaznaczono, że każde zachowanie indywidualne jak też zbiorowe skierowane „w celu przeistoczenia lub zamieszania porządku publicznego" istniejącego w państwach pozostających pod panowaniem trzech opiekuńczych monarchów, a także uczestniczenie w takich działaniach, stanowić będzie pogwałcenie ścisłej neutralności, i jako takie będzie ścigane i karane przez władze krajowe, jako przestępstwo polityczne. Ponadto wprowadzono bezwzględny zakaz przyjmowania osób ściganych, zbrodniarzy, dezerterów oraz obowiązek ich wydawania na żądanie władz państw sąsiadujących (Kallas M., Krzymkowski M., 2006, s.190-201). A zatem w konstytucjach Wolnego Miasta Krakowa pojęcie „bezpieczeństwo wewnętrzne” służyło do określenia charakteru służb porządkowych tj. milicji i żandarmerii. Natomiast pojęcie „porządek publiczny” użyte w konstytucji z 1833 r. określało ten ,porządek” jako wartość konstytucyjną podlegającą ochronie władz państwowych.

Szczegółowe regulacje prawne dotyczące ochrony porządku i bezpieczeństwa publicznego wydawane były głównie przez Senat, który posiadał wyłączną kompetencję do kreowania organów administracyjnych, a także do określania ich zadań. W tym zakresie kluczowe znaczenie miało Urządzenie wewnętrzne Senatu Wolnego Miasta Krakowa i Jego Okręgu z dnia 15 lipca 1816 r., w którym określono kompetencje Wydziału Policji i Milicji tegoż Senatu oraz Biura Policji Pośredniej. Wydział ten miał m.in. czuwać nad bezpieczeństwem publicznym i osobistym, obyczajami publicznymi, jakością i uczciwości praktyk handlowych, policją lekarską, czystością w kraju i oświetleniem Krakowa, ochroną przeciwpożarową, miał także zapobiegać żebractwu, włóczęgostwu oraz czuwać nad przestrzeganiem art. 6 traktatu dodatkowego (§50) (Dz. Rozp. Rządowych WMK 1816,nr 2104). W 1822 r. większość z tych zadań przejął nowy wydział Senatu pod nazwą: Wydział Spraw Wewnętrznych i Policji (Cichoń P., 2014, s.79). Ciężar faktycznego wykonywania tych zadań powierzono Biuru Policji Pośredniej, które powołane zostało „dla utrzymania porządku wewnętrznego miasta [Krakowa - P.C], sprężystości w działaniu i zapew-

(C) 2018 /Published by: Międzynarodowy Instytut Innowacji Nauka-Edukacja-Rozwój w Warszawie, Polska

This is an open access article under the CC BY-NC license

(http://creativecommons.org/licenses/by-nc/4.0/)

Cichoń P. (2018). Protection of Public Order and Safety in The Legislation of The Free City of Cracow 1815-1846. International Journal of Legal Studies, 1(3)2018; 337-357

DOI 10.5604/01.3001.0012.2183 
nienia spokojności i bezpieczeństwa publicznego" (§ 84) (Dz. Rozp. Rządowych WMK 1816, nr 2104.).

$\mathrm{Z}$ punktu widzenia rozległości regulacji prawnych dotyczących różnych aspektów związanych z ochroną porządku i bezpieczeństwa publicznego szczególne znaczenia miały akty prawne dotyczące Dyrekcji Policji, która w 1827 r. zajęła miejsce Biura Policji Pośredniej. Były to rozporządzenia Senatu Rządzącego: z dnia 13 lipca 1827 r. (Dziennik Praw RK 1827, nr 3344 D.G.S.) (zwane dalej Statutem DP), z dnia 1 listopada 1833 r. (Dz. Praw 1834, nr 2736 D.G.S.) (pt. Reorganizacja policji w Mieście Krakowie. Instrukcja i granice tejże władzy zakreślająca - zwana dalej Nową Instrukcją), z dnia 18 lutego 1840 r. (Dz. Praw 1840, nr 10 D.K.) (zwane dalej - Drugim Statutem DP). Zgodnie z § 214 Drugiego Statutu DP dotychczasowe przepisy zawarte w Statucie DP z 1827 r. oraz w Nowej Instrukcji z 1833 r. „o ile mieściły w sobie przepisy przeciwne I części nowego statutu, traciły swoją moc obowiązującą" ( Dz. Praw 1840, nr 10 D.K.). Dyrekcja Policji zgodnie z przepisami z 1827 r. miała czuwać nad utrzymaniem w państwie porządku i bezpieczeństwa publicznego. Dodatkowo w Drugim Statucie DP z 1840 r. wskazano, że czuwać miała „bezpośrednio w kraju nad utrzymaniem porządku i bezpieczeństwa tak publicznego, jako też prywatnego poszczególnych osób" (art. 1). Można zatem, przez pryzmat kompetencji tego organu spróbować określić jakie obszary problemowe zawierały się $\mathrm{w}$ pojęciu ,porządek publiczny” oraz „bezpieczeństwo publiczne”.

Oprócz ww. aktów normatywnych obowiązywało jeszcze szereg innych szczegółowych regulacji prawnych, które dotyczyły wąsko określonych problemów dotyczących ochrony porządku i bezpieczeństwa publicznego. Były to głównie rozporządzenia Senatu, który wydawano stosownie do aktualnych potrzeb, w tym również w celu republikacji dotychczasowych przepisów, „które poszły w zapomnienie” lub też w celu likwidowania pojawiających się zagrożeń. Senat wydawał też instrukcje dla milicji, żandarmerii i policji, określające szczegółowe zasady odbywania służby patrolowej, przeprowadzania rewizji i wykonywania innych czynności związanych z zabezpieczaniem porządku i bezpieczeństwa publicznego (Cichoń P., 2014, s.162-167, 238-248)(Cichoń P., 2012, s.55-71)( Namysłowski, W. 1913).

(C) 2018 /Published by: Międzynarodowy Instytut Innowacji Nauka-Edukacja-Rozwój w Warszawie, Polska 
Analizując ustawodawstwo władz krajowych en bloc z czasów Wolnego Miasta Krakowa można stwierdzić, że zachowanie bezpieczeństwa publicznego miało polegać na utrzymaniu nienaruszalności życia, zdrowia, godności czyli honoru, wolności, mienia oraz porządku prawnego. Zakres rozumienia istoty bezpieczeństwa ściśle wiązał się z problemami występujących zagrożeń. Pomiędzy nimi występowała więc wyraźna koherencja powodująca, że charakter i skala zagrożeń miały wpływ na stan bezpieczeństwa jednostki, społeczeństwa jak i całego państwa. Z kolei potrzeby w tym zakresie warunkowały wybór sposobów i metod działania, które miały doprowadzić do eliminowania tych zagrożeń oraz osiągnięcia stanu braku lęku i spokoju. Z kolei zapewnienie porządku publicznego miało polegać na egzekwowaniu przestrzegania przez ludność w swym postępowaniu przepisów prawnych, których nieprzestrzeganie $w$ warunkach zbiorowego współżycia ludzi narażałoby ich na niebezpieczeństwa i uciążliwości. Wiązało się to także z ochroną przed ludzką nieostrożnością oraz brakiem przewidywania, a nie tylko przed złą wolą człowieka. Przedmiotowa rozpiętość regulacji policyjno-administracyjnych obowiązujących w Rzeczypospolitej Krakowskiej była bardzo duża, dlatego w dalszej części artykułu przedstawione zostaną jedynie wybrane przykłady, które najlepiej pokazują obszary problemowe, które mieściły się w pojęciach „porządek publiczny” oraz „bezpieczeństwo publiczne".

Jednym z kluczowych zadań związanych z dbaniem o porządek publiczny na obszarze Wolnego Miasta Krakowa było przeciwdziałanie i niwelowanie patologii społecznych, tj. żebractwa i włóczęgostwa, które występowały nagminnie i stanowiły poważne zagrożenie dla porządku publicznego. Pierwsze lokalne regulacje prawne dotyczące tej kwestii wydane zostały 5 lutego 1817 r. Celem tych przepisów była ochrony mieszkańców Krakowa przed natręctwem bezdomnych, a z drugiej strony chęć zapewnienia pomocy w formach zorganizowanych osobom bezdomnym i bezrobotnym. Wprowadzono powszechny zakaz włóczęgostwa i żebractwa, a eliminowanie niepożądanych jednostek z Krakowa i jego przedmieść jak również wyciąganie konsekwencji prawnych wobec osób dopuszczających się takich zachowań powierzono organom policyjnym. Bezdomni pochodzący z okręgu byli usuwani z Krakowa, cudzoziemcy wydalani z kraju w drodze tzw. schubpassu, a miejscowi zależ-

(C) 2018 /Published by: Międzynarodowy Instytut Innowacji Nauka-Edukacja-Rozwój w Warszawie, Polska

This is an open access article under the CC BY-NC license

(http://creativecommons.org/licenses/by-nc/4.0/)

Cichoń P. (2018). Protection of Public Order and Safety in The Legislation of The Free City of Cracow 1815-1846. International Journal of Legal Studies, 1(3)2018; 337-357

DOI 10.5604/01.3001.0012.2183 
nie od stanu zdrowia przekazywani pod opiekę Towarzystwa Dobroczynności lub do Domu Pracy Przymusowej (Dz. Roz. Rządowych WMK 1817, nr 386.).

W Nowej instrukcji z 1833 r. zwalczanie włóczęgostwa i żebractwa, które nadal były bezwzględnie zakazane powierzono Dyrekcji Policji. W tym akcie prawnym stypizowano też lekkie przestępstwa policyjne $\mathrm{z}$ tej kategorii oraz określono kary za ich popełnienie (art. 207, pkt 70) (Dz. Praw 1834, nr 2736 D.G.S.). Nieskuteczność dotychczasowych działań w walce $\mathrm{z}$ żebractwem spowodowała, że Senat Rządzący 3 lipca 1840 r. wydał nowe rozporządzenie dotyczące tej kwestii. Zwalczaniem tego zjawiska nadal zajmowała się Dyrekcja Policji na obszarze Krakowa, a komisarze dystryktowi w okręgu. Zatrzymane osoby zależnie od ich pochodzenia i stanu zdrowia kierowano do Domu Schronienia, Domu Pracy Przymusowej (lub do oddziału filialnego w Jaworznie) lub wydalano z Krakowa lub z całego kraju. W sytuacji, gdy bezdomni ze względu na brak wolnych miejsc nie mogli zostać umieszczeni w Domu Schronienia, otrzymywali specjalne zaświadczenie, które pozwalało im legalnie żebrać. Zaostrzono też odpowiedzialność karną wobec osób zatrzymanych na tym procederze (art. 9-12) (Dz. Praw 1840, s. 1-2, nr 287 D.G.S.).

Instytucjonalne zwalczanie żebractwa i włóczęgostwa $\mathrm{z}$ czasem powiązane zostało z działalnością Domu Pracy Przymusowej. Zgodnie z założeniami ustawy z 3 stycznia 1822 r. osadzeniu w tym domu podlegali zdolni do pracy fizycznej: „włóczędzy, ludzie podejrzani lub bez służby zostający i inni niemogący się wywieść ze sposobu właściwego utrzymania życia” (art. 1) (Dz. Roz. Rządowych WMK 1822, nr 58 D.G. Faktycznie został utworzony dopiero na mocy rozporządzenia Senatu z dnia 15 VI 1827 r., Dz. Praw RK 1827, nr 3999.). Dom Pracy Przymusowej był zakładem o więziennym charakterze, a pobyt $\mathrm{w}$ nim miał przyczyniać się do podwyższenia poziomu moralnego, reedukacji nieproduktywnych i skłonnych do występków ludzi. Miał także służyć wyrobieniu u nich nawyku uczciwej pracy na własne utrzymanie. Kolejnym zadaniem związanym bezpośrednio z ochroną bezpieczeństwa i porządku publicznego nie tylko na terenie Wolnego Miasta Krakowa, ale i krajów sąsiednich było prowadzenie odpowiedniej polityki paszportowej w tym wydawanie i wizowanie paszportów. W tym zakresie bardzo ważną rolę odgrywała od 1827 r. Dyrekcja Policji i jej dyrektor, który osobiście wystawiał i podpisywał każdy paszport (dodat-

(C) 2018 /Published by: Międzynarodowy Instytut Innowacji Nauka-Edukacja-Rozwój w Warszawie, Polska

This is an open access article under the CC BY-NC license (http://creativecommons.org/licenses/by-nc/4.0/) 
kowo podpis składał sekretarz Dyrekcji Policji). Kompetencje tego organu przewidywał art. 6 w zw. z art. 29a Statutu DP z 1827 r. Te instrumenty prawne były bardzo ważne, gdyż wizowanie paszportów otwierało cudzoziemcom możliwość pobytu w Wolnym Mieście Krakowie, co było równoznaczne z uznaniem, że nie stanowili oni zagrożenia dla istniejącego ładu i porządku prawnego. Z kolei otrzymanie paszportu przez mieszkańca Rzeczypospolitej Krakowskiej pozwalało mu na wyjazd do sąsiednich krajów lub dalszej podróży. Od lat trzydziestych systematycznie zaostrzano przepisy paszportowe, co wiązało się z negatywną oceną ze strony mocarstw opiekuńczych tych mieszkańców Wolnego Miasta Krakowa, którzy sympatyzowali z powstańcami z Królestwa Polskiego, niejednokrotnie udzielając im schronienia, pomocy medycznej lub materialnej. W 1832 r., Senat Rządzący wydał przepisy pod względem „zabezpieczenia legalnego użycia paszportów przez Dyrekcję Policji”, które miały zapobiegać posługiwaniu się paszportami przez osoby nieuprawnione. Wprowadzono też odpowiedzialność karną za usiłowanie jak i odstąpienie paszportu innej osobie, a także za posługiwanie się paszportem innej osoby (pkt 1). Przewidziano także konsekwencje prawne dla osób, które w wyniku niedbalstwa lub lekkomyślności przyczyniły się do kradzieży lub zagubienia własnego paszportu (art. 4) (Dziennik Rządowy Wolnego Miasta Krakowa 1832, nr 31, s. 125-127, nr 5024 D.G.S. (dalej Dz. Rządowy WMK). Ponowna publikacja tych przepisów nastąpiła w Dz. Rządowym WMK 1835, nr 46-47, s. 180-182, nr 7054 D.G.S.). W Nowej Instrukcji z 1833 r. wprowadzono kolejne obostrzenia paszportowe. Dokument podróży mogły otrzymać tylko osoby, które przedstawiły zaświadczenie z rodzimej gminy o nieposzlakowanej opinii (art. 40) (Dz. Praw 1834, nr 2736 D.G.S.). Poza tym Dyrekcja Policji zobowiązana została do codziennego przesyłania rezydentom Austrii, Prus i Rosji listy cudzoziemców przyjeżdżających i wyjeżdżających z Krakowa (art. 41). Celem tych zmian prawnych było zminimalizowanie ryzyka przyjazdu i wyjazdu za granicę osób, które ze względu na swoją wcześniejszą działalność przestępczą, konspiracyjną lub niepodległościową były niepożądane w krajach sąsiednich. A zatem rygorystyczna polityka paszportowa miała przyczyniać się do skuteczniejszej ochrony porządku i bezpieczeństwa publicznego na terenie Austrii, Prus i Rosji, na czym bardzo zależało władzom tych państw (Cichoń P., 2014, s. 273-277). Nowa Instruk-

(C) 2018 /Published by: Międzynarodowy Instytut Innowacji Nauka-Edukacja-Rozwój w Warszawie, Polska

This is an open access article under the CC BY-NC license

(http://creativecommons.org/licenses/by-nc/4.0/)

Cichoń P. (2018). Protection of Public Order and Safety in The Legislation of The Free City of Cracow 1815-1846. International Journal of Legal Studies, 1(3)2018; 337-357 DOI 10.5604/01.3001.0012.2183 
cja $\mathrm{z} 1833$ r. zawierała też dodatkowy katalog przestępstw policyjnoadministracyjnych związanych z niewłaściwym posługiwaniem się paszportami (art. 207, pkt. 83-85) (Dz. Praw 1834, nr 2736 D.G.S.).

W okresie okupacji Rzeczypospolitej Krakowskiej przez wojska mocarstw opiekuńczych począwszy od lutego 1836 r., wprowadzone zostały jeszcze bardziej rygorystyczne przepisy paszportowe, które uzasadniane były koniecznością zmaksymalizowania ochrony bezpieczeństwa publicznego w regionie (Dz. Praw 1836, nr 6908 D.G.S.). Również w Drugim Statucie DP z 1840 r. przewidziano ważną rolę Dyrekcji Policji w realizacji polityki paszportowej zgodnej z oczekiwaniami mocarstw opiekuńczych (§ 59, 90-94) (Dz. Praw 1840, nr 10 D.K.). Poza tym dnia 15 marca 1841 r. Senat Rządzący wydał rozporządzenie wprowadzające zakaz opuszczania obszarów „,pod berłem protegujących mocarstw zostających” bez paszportu jak również samowolnego przedłużania pobytu poza granicami krajów sąsiednich ponad termin określony w paszporcie (Dz. Praw 1841, nr 1492 D.G.S.).

Ważne znaczenie z punktu widzenia ochrony bezpieczeństwa i porządku publicznego miały również regulacje prawne dotyczące kontroli ruchu ludności wewnątrz kraju. Pierwsze przepisy dotyczące ewidencji ludności na terenie Wolnego Miasta Krakowa wydane zostały 29 sierpnia 1816 r., w związku z tym pewne zadania w tym zakresie nałożone zostały na Biuro Policji Pośredniej oraz na wójtów w gminach wiejskich. Środkiem, który temu służył była prowadzona księga ludności, oparta na szeroko określonym obowiązku meldunkowym. Pozwalało to organom administracyjnym i policyjnym na pozyskiwanie, gromadzenie i przetwarzanie informacji istotnych dla bezpieczeństwa publicznego, związanych m.in. ze zwalczaniem włóczęgostwa oraz zatrzymywaniem osób podejrzanych lub poszukiwanych. W Nowej Instrukcji z 1833 r. na nowo zdefiniowano obowiązki meldunkowe oraz zadania ewidencyjne Dyrekcji Policji (art. 106-122) (Dz. Praw 1834, nr 2736 D.G.S.). W 1836 r. doszło do republikacji przepisów meldunkowych z 1824 r. (Dz. Rządowy WMK 1836, nr 11-12, s 42-43, nr 1421 D.G.S.). Od 1837 r. rola Dyrekcji Policji w realizacji obowiązków ewidencyjnych istotnie wzrosła, a obowiązek meldunkowy na terenie Krakowa realizowano wyłącznie w tej Dyrekcji z pominięciem wójtów (Dz. Rządowy WMK 1837, nr 33-34, s. 129-131, nr 1095 D.G.S.). Bezwzględne egze-

(C) 2018 /Published by: Międzynarodowy Instytut Innowacji Nauka-Edukacja-Rozwój w Warszawie, Polska

This is an open access article under the CC BY-NC license

(http://creativecommons.org/licenses/by-nc/4.0/)

Cichoń P. (2018). Protection of Public Order and Safety in The Legislation of The Free City of Cracow 1815-1846. International Journal of Legal Studies, 1(3)2018; 337-357

DOI 10.5604/01.3001.0012.2183 
kwowanie przepisów meldunkowych leżało zarówno w interesie władz lokalnych jak i mocarstw opiekuńczych. Realizacja tego obowiązku nabierała szczególnego znaczenie $\mathrm{w}$ okresach interwencji zbrojnych i okupacji podejmowanych przez mocarstwa opiekuńcze, a podwyższone wówczas sankcje karne za niedopełnienie obowiązków meldunkowych miały dyscyplinować do ich wykonania. Dyrekcji Policji, a w okręgu wójtom, a później komisarzom dystryktowym powierzano ponadto egzekwowanie przepisów porządkowych określających godziny policyjne i zasady poruszania się po ulicach po zmroku (Cichoń P., 2014, s. 289-290).

W Wolnym Mieście Krakowie wydano bardzo liczne regulacje prawne dotyczące działalności podmiotów gospodarczych, zwłaszcza handlowo-usługowych. Celem tych przepisów było nie tylko utrzymanie porządku w tym zakresie, ale także poprawa bezpieczeństwa obrotu gospodarczego oraz ochrona życia i zdrowia oraz moralności publicznej. Wiązała się to m.in. z wydawaniem zezwoleń na prowadzenie takiej działalności po spełnieniu niekiedy bardzo szczegółowych warunków określonych w tych przepisach. Dotyczyło to m.in. prowadzenie szynków (Dz. Praw 1839, nr 3388 D.G.S.; Dz. Praw 1839, nr 7009 D.G.S.), grania w nich muzyki - co było instrumentem walki z pijaństwem (Dz. Rządowy WMK 1831, nr 2, s. 5-7, nr 2927 D.G.S.; Dz. Rządowy WMK 1939, nr 15-16, nr 1167 D.G.S.), zatrudniania kobiet w takich lokalach - co miało służyć zwalczaniu nielegalnej prostytucji (Dz. Rządowy WMK 1829, nr 9, s. 35-36, nr 929.), prowadzenia pensji dla młodzieży (Dz. Praw 1842, nr 5271 D.G.S.), sprzedaży zboża (Dz. Rządowy WMK 1830, nr 12-13, s. 4548, nr 1168.), opału (Archiwum Narodowe w Krakowie, WM-588, k. 4, nr 4882.), alkoholu (Dz. Praw 1845, nr 915 D.G.S.) itp. Tego rodzaju akty prawne zawierały też przepisy regulujące kompetencje i tryb przeprowadzania kontroli prowadzonej działalności oraz jakości sprzedawanych towarów i świadczonych usług. Np. regularne kontrole placów targowych miały przyczyniać się do prowadzenia handlu zgodnie z ustalonym planem dyslokacji, ustalonymi urzędowo dniami i godzinami handlu hurtowego i detalicznego oraz ogłoszonymi wykazami cen urzędowych. Kontrolowano też jakość sprzedawanych produktów, m.in. spożywczych i rzemieślniczych, oznakowanie produktów wprowadzanych do obrotu, itd. Uprawnienia kontrolne powierzono Dyrekcji Policji, która przy pomocy komisarzy i rewizorów policji oraz komi-

(C) 2018 /Published by: Międzynarodowy Instytut Innowacji Nauka-Edukacja-Rozwój w Warszawie, Polska

This is an open access article under the CC BY-NC license

(http://creativecommons.org/licenses/by-nc/4.0/)

Cichoń P. (2018). Protection of Public Order and Safety in The Legislation of The Free City of Cracow 1815-1846. International Journal of Legal Studies, 1(3)2018; 337-357 DOI 10.5604/01.3001.0012.2183 
sarza targowego miała realną możliwość zwalczania potencjalnych zagrożeń dla uczciwej konkurencji jak i indywidualnych konsumentów, np. egzekwując zakaz sprzedaży hurtowej na targach przed godziną 11:00. Rygorystycznie zwalczano także defraudację mięsa i innych produktów spożywczych, w szczególności sprzedaż mięsa z bydła i trzody, które bito poza szlachtuzem generalnym (Cichoń P., 2014, s.308318). Ważnym instrumentem, który pomagał w realizacji funkcji inspekcji handlowej było przekazanie administracji policyjnej kompetencji do kontroli urządzeń pomiarowych stosowanych w handlu, a od $1836 \mathrm{r}$. dodatkowo uprawnień do ich legalizowania (Dz. Praw 1836, nr 6299 D.G.S.). Ponadto na mocy przepisów z 1845 r. wprowadzono administracyjny nadzór nad sprzedażą wyrobów jubilerskich, co miało zapobiegać nielegalnej sprzedaży tych wyrobów pochodzących z zagranicy (Dz. Praw 1845, nr 472 D.G.S.).

Kolejnym przykładem działań przewidzianych w Nowej Instrukcji z 1833 r. było zapewnienie porządku i bezpieczeństwa publicznego w sferze budowlanej, czyli swoisty nadzór budowlany. Celem tych działań było przeciwdziałanie samowolnemu realizowaniu prac remontowo-budowlanych na terenie Krakowa, co podyktowane było nie tylko chęcią unikania zagrożeń w postaci katastrof budowlanych, ale również utrzymaniem estetyki i porządku architektonicznego w Mieście. Kompetencje nadzorcze w tym zakresie powierzono także Dyrekcji Policji, która miała czuwać nad tym, aby prace budowlane jak też usługi kominiarskie wykonywały osoby mające do tego odpowiednie kwalifikacje (art. 155-156) (Dz. Praw 1834, nr 2736 D.G.S.).

Na mocy rozporządzenia senatu z 18 lutego 1842 r. Dyrekcja Policji dodatkowo zajmowała się kontrolą jakości materiałów budowlanych produkowanych i sprzedawanych na terenie Miasta jak również importowanych do kraju. Przewidziano w nim bardzo restrykcyjne sankcje za sprzedaż niespełniających norm technicznych materiałów, włącznie z ich konfiskatą. W przypadku, gdy producent pomimo trzykrotnego ukarania nadal produkował wadliwe materiały budowlane, Dyrekcja mogła wobec niego orzec karę przymusowego zamknięcia cegielni. W stosunku zaś do zagranicznych fabryk, mogła wprowadzić embargo na ich produkty. Realizacja tych uprawnień mogła przyczyniać się do minimalizowania zagrożeń dla życia i zdrowia związanych z używaniem złej jakości materiałów budowlanych. Podnosiło to poziom

(C) 2018 /Published by: Międzynarodowy Instytut Innowacji Nauka-Edukacja-Rozwój w Warszawie, Polska

This is an open access article under the CC BY-NC license

(http://creativecommons.org/licenses/by-nc/4.0/)

Cichoń P. (2018). Protection of Public Order and Safety in The Legislation of The Free City of Cracow 1815-1846. International Journal of Legal Studies, 1(3)2018; 337-357

DOI 10.5604/01.3001.0012.2183 
bezpieczeństwa budowlanego szczególnie na terenie Krakowa. (§ 4-6, 7, 14-15) (Dz. Praw 1842, nr 846 D.G.S.).

Nowa instrukcja z 1833 r. wprowadziła też nową kategorię zadań związanych z zapewnieniem ,spokojności publicznej”, co bezpośrednio przyczyniało się do utrzymania porządku i bezpieczeństwa publicznego na terenie Wolnego Miasta Krakowa. W tym zakresie, Dyrekcja Policji miała dbać o spokój i porządek w miejscach publicznych, zapobiegać wybrykom słownym i innym nielegalnym zachowaniom. Wprowadzono też obowiązek rejestracji stowarzyszeń, ale po wcześniejszym przekonania się „o użyteczności i godziwych celach onegoż” (art. 123-124) (Dz. Praw 1834, nr 2736 D.G.S.). Takie nieostre sformułowanie pozwalało na daleko idącą uznaniowość przy jego wykładni. Biorąc pod uwagę sytuację polityczną w Wolnym Mieście Krakowie, z całą pewnością nie mogły liczyć na akceptację ze strony władz związki o charakterze patriotycznym czy narodowym, gdyż ich cele mogłyby zagrażać podstawom ustrojowym tego państwa, opartym na formalnej zależności od Austrii, Prus i Rosji.

W celu „zapewnienia spokojności publicznej” przewidziano także nadzór nad zakładami drukarskimi, litograficznymi oraz księgarniami. Jego celem było tropienie wydawnictw zakazanych, a działania Dyrekcji Policji wspólnie z Komitetem Cenzury stały się narzędziem w procesie eliminowania wszelkich przejawów niezadowolenia $\mathrm{z}$ istniejącej sytuacji politycznej w kraju oraz jego zależności od mocarstw opiekuńczych (art. 125-126) (Dz. Rządowy WMK 1832, nr 36-37, s. 145-152, nr 5918 D.S.; Dz. Praw 1834, nr 2736 D.G.S.). Korespondowało z tym wprowadzenie reglamentacji prawnej na wystawianie widowisk, sztuk teatralnych jak również organizowanie zgromadzeń publicznych. Warunkiem uzyskania pozwolenia na ich odbycie było wcześniejsze zweryfikowanie, czy treść lub program ,nic takiego w sobie nie obejmuje, co by religii, moralności lub interesom kraju tego, jako też sąsiedzkich uwłaczać lub szkodzić mogło"(art.127-130) (Dz. Rządowy WMK 1832, nr 36-37, s. 145-152, nr 5918 D.S.; Dz. Praw 1834, nr 2736 D.G.S.).

Dbając o „spokojność publiczną”, władze policyjne miały również zabezpieczać pokojowy przebieg uroczystości państwowych, a także imprez towarzyskich, zarówno prywatnych jak i oficjalnych (art.132-134) [Np. w styczniu 1830 r. Dyrek-

(C) 2018 /Published by: Międzynarodowy Instytut Innowacji Nauka-Edukacja-Rozwój w Warszawie, Polska

This is an open access article under the CC BY-NC license

(http://creativecommons.org/licenses/by-nc/4.0/)

Cichoń P. (2018). Protection of Public Order and Safety in The Legislation of The Free City of Cracow 1815-1846. International Journal of Legal Studies, 1(3)2018; 337-357

DOI 10.5604/01.3001.0012.2183 
cja Policji stosownie do postanowienia Wydziału Spraw Wewnętrznych i Policji z 24 I 1830 r. wydała „Przepisy dla utrzymania porządku na publicznych balach w Wolnym Mieście Krakowie”(Cichoń P., 2014, s.326)].

Nowa instrukcja z 1833 r. zawierała też przepisy służące ochronie „bezpieczeństwa osób i ich własności”. Wprowadzono generalny zakaz noszenia broni w miejscach publicznych $w$ tym broni białej w postaci ostrzy ukrytych w przedmiotach niemających wyglądu broni, a także sztyletów oraz broni palnej. Osoby naruszające ten zakaz narażały się na odpowiedzialność karną (art. 135-148) (Dz. Praw 1834, nr 2736 D.G.S.). W Nowej Instrukcji z 1833 r. przewidziano również instrumenty służące ochronie życia i zdrowia mieszkańców Krakowa, tj. urzędowe wyznaczanie bezpiecznych kąpielisk na Wiśle i Rudawie (osobnych dla mężczyzn i kobiet - art. 137-138). Przewidziano również administracyjny nadzór nad porządkiem, czystością i bezpieczeństwem w łaźniach publicznych, a także nad ich wyposażeniem (,w dzwonki na przypadek słabości kąpiących się"- art.147) (Dz. Praw 1834, nr 2736 D.G.S.).

Akty prawne określały też tryb i zakres kontroli lokali rozrywkowych i obiektów noclegowych. Głównym celem tych działań było dążenie do wykrycia osób podejrzanych, poszukiwanych lub nielegalnie przebywających na terytorium kraju (art. 144).

Wprowadzano też przepisy chroniące młodzież przed demoralizacją w tym zakaz uczęszczania przez nią do lokali rozrywkowych, w których podawano alkohol, jak również do domów publicznych. Przewidywano administracyjny nadzór nad prowadzeniem i otwieraniem szynków, domów zajezdnych oraz bilardów. Zwalczano też nielegalny hazard oraz kontrolowano prostytucję, która w pewnym zakresie była dozwolona (art. 141-146) (Dz. Praw 1834, nr 2736 D.G.S.).

$\mathrm{W}$ razie pojawiających się zagrożeń związanych z ryzykiem wystąpienia chorób zakaźnych wydawano też przepisy nakładające powszechne obowiązki związane z profilaktyką i zwalczaniem tego typu zagrożeń [Np. Dyrekcja Policji pełniła aktywną rolę w zwalczaniu panującej w Krakowie w 1831 r. zarazy cholery (Bieniarzówna J., Małecki J.M., 1979, s.78-79)]. Dotyczyło to także zwalczania epidemii

(C) 2018 /Published by: Międzynarodowy Instytut Innowacji Nauka-Edukacja-Rozwój w Warszawie, Polska 
chorób zwierząt, m.in. poprzez wprowadzanie kwarantanny na określonym obszarze czy czasowych ograniczeń w zakresie handlu bydłem (Cichoń P., 2014, s. 321-324).

Ważnym aspektem związanym z ochroną życia i zdrowia mieszkańców była troska o właściwy stan sanitarny ujęć wody (art.139). Nowa instrukcja z $1833 \mathrm{r}$. zawiera też rozbudowane przepisy dotyczące bezpieczeństwa sanitarnego związane z zakazami sprzedaży szkodliwych dla zdrowia niedojrzałych owoców, śniętych ryb, zepsutego mięsa, niewypieczonego chleba itp. (art.180). Na Dyrekcję Policji nałożono obowiązek niezwłocznego zawiadomienia Wydziału Spraw Wewnętrznych i Policji w Senacie Rządzącym o każdym przypadku śmierci spowodowanej chorobą zakaźną w celu podjęcia działań zabezpieczających przed epidemią [Podejmowano też działania profilaktyczne, np. szczepienia przeciwko ospie. Zasady dotyczące szczepień przeciwko ospie opublikowane zostały w (Dz. Rządowym WMK 1842, nr 3233, s. 127-128, nr 1408)].

Kolejnym obszarem, który podlegał regulacjom prawnym i wiązał się z porządkiem i bezpieczeństwem publicznym była troska o utrzymywanie czystości i porządku na terenie Krakowa. Pierwszą regulacją prawną, która przewidywała pewne obowiązki straży policyjnej w tym zakresie było rozporządzenie z 15 listopada 1816 r. [„Przepis ochędostwa i porządku w Mieście Krakowie, obowiązujący właścicieli domów lub ich zastępców do zachowania”, (Dz. Rządowy WMK 1816, przepis ten został opublikowany oddzielnie (brak numeru dziennika), nr 816). Dodatkowe przepisy regulujące obowiązki związane z zachowaniem czystości na ulicach i placach publicznych w Krakowie wydano 9 maja 1833 r. (Dz. Rządowy WMK 1833, nr 1314, s. 46-48, nr 2411 D.G.S.). Celem tych przepisów było zobowiązanie mieszkańców Krakowa do ochrony zdrowia jak również do utrzymywanie czystości i higieny na obszarze Miasta. W Nowej Instrukcji z 1833 r. określono także liczne zadania z tym związane (art. 183-190). Stypizowano też szereg lekkich przestępstw policyjnych związanych z naruszeniami zasad związanych z utrzymaniem czystości w mieście w tym sprzątaniem ulic i odśnieżaniem dachów i ulic (art. 207, pkt. 59). Innym przejawem troski o porządek w mieście, a także o ochronę przed nieprzyjemnymi zapachami było zwalczanie nielegalnej hodowli zwierząt gospodarskich na terenie miasta Krakowa (art. 207, pkt. 62-64) (Dz. Praw 1834, nr 2736 D.G.S.).

(C) 2018 /Published by: Międzynarodowy Instytut Innowacji Nauka-Edukacja-Rozwój w Warszawie, Polska

This is an open access article under the CC BY-NC license

(http://creativecommons.org/licenses/by-nc/4.0/)

Cichoń P. (2018). Protection of Public Order and Safety in The Legislation of The Free City of Cracow 1815-1846. International Journal of Legal Studies, 1(3)2018; 337-357 DOI 10.5604/01.3001.0012.2183 
Wiele miejsca poświęcano także w aktach prawnych kwestiom związanym z tzw. policją ogniową czyli z bezpieczeństwem przeciwpożarowym. W Krakowie w ramach austriackich przepisów ogniowych z 22 kwietnia 1803 r., Senat wydał w kwietniu i maju 1818 r. dwa zarządzenia dotyczące zorganizowania służby przeciwpożarowej w Krakowie oraz lokalizowania wozów z beczkami i kadzi z wodą (Wachholz Sz., 1957, s. 383).

W Nowej Instrukcji z 1833 r. zamieszczono również szereg przepisów dotyczących ochrony przeciwpożarowej. M.in. pod groźbą kary zabroniono składowania materiałów łatwopalnych $\mathrm{w}$ drewnianych pomieszczeniach, a także palenia tytoniu $\mathrm{w}$ miejscach publicznych jak i używania otwartego ognia w takich miejscach, jak i w stajniach, w domach zajezdnych, oberżach, sklepach z alkoholem itp. W takich obiektach wolno było posługiwać się jedynie zamkniętymi latarniami. Zalecano też zakładanie stajni w pomieszczeniach z murowanym sklepieniem z zamontowanymi na stałe latarniami (art. 157-163) (Dz. Praw 1834, nr 2736 D.G.S.). Przepisy prawne nakładały też osobiste obowiązki związane $\mathrm{z}$ udziałem $\mathrm{w}$ gaszeniu pożarów oraz posiadania odpowiedniego sprzętu gaśniczego (art. 207 pkt. 80, 98-100). Egzekwowanie przez służby policyjne takich obowiązków miało zwiększać skuteczność akcji gaśniczych, a zarazem podnosić świadomość społeczną związaną z istnieniem osobistego obowiązku uczestniczenia w akcji gaśniczej przez właścicieli domów położonych w bezpośrednim sąsiedztwie pożaru lub przez ich służbę (Cichoń P., 2014, s. 307).

Austriackie przepisy przeciwpożarowe z 1803 r. obowiązywały do 1842 r., kiedy zastąpiono je nowym rozporządzeniem z dnia 6 grudnia 1841 r. pt. Urządzenie ogniowe dla Wolnego Miasta Krakowa i jego Okręgu (Dz. Praw 1842, nr 6513 D.G.). Przepisy te regulowały zarówno kwestie profilaktyki przeciwpożarowej, jak również organizację i przebieg akcji ratowniczo-gaśniczych oraz zabezpieczanie rzeczy pogorzelców. Zapewnienie bezpieczeństwa przeciwpożarowego wiązało się także z egzekwowaniem przepisów dotyczących prawidłowego stawiania kominów jak również regularnego ich czyszczenia. Ten akt prawny określał też zasady dotyczące prowadzenia fabryk oraz warsztatów rzemieślniczych w których używano otwartego ognia.

(C) 2018 /Published by: Międzynarodowy Instytut Innowacji Nauka-Edukacja-Rozwój w Warszawie, Polska 
Ochrona porządku i bezpieczeństwa publicznego w Wolnym Mieście Krakowie wiązała się także ze zwalczaniem przestępczości. Czynności dochodzeniowośledcze na terenie Krakowa wykonywało Biuro Policji Pośredniej, a później Dyrekcja Policji, a w okręgu krakowskim wójtowie, z czasem zaś komisarze dystryktowi (art. 2, art. 12) (Dz. Praw RK 1827, nr 3344 D.G.S). Od 1839 r. Dyrekcja Policji podejmowała takie czynności także w sprawach przestępstw, które miały miejsce w obrębie gmin administracyjnie włączonych do Krakowa. Wtedy powierzono jej też kompetencje sądownicze w sprawach ciężkich przestępstw policyjnych. Uzasadniając zmiany przepisów dotyczących organizacji sądownictwa wskazano, że celem ich było zwiększenie bezpieczeństwa wewnętrznego kraju i „spokojności Państw sąsiednich" [Na mocy Urządzenia biegu służby sprawiedliwości karnej z 2 VII 1839 r. (Dz. Praw 1839, nr 23)]. Ponadto w Drugim Statucie DP z 1840 r. określono, że do jej kompetencji należało orzekanie we wszystkich sprawach ciężkich przestępstw policyjnych popełnionych na obszarze Miasta oraz gmin administracyjne włączonych do Krakowa (§ 14) (Dz. Praw 1840, nr 10 D.K.). Z kolei od 1842 r. w odniesieniu do ciężkich przestępstw policyjnych naruszających bezpieczeństwo publiczne, spokojność publiczną oraz dotyczących obrazy warty cywilnej lub wojskowej, Dyrekcja Policji uzyskała wyłączność zarówno $\mathrm{w}$ prowadzeniu dochodzeń jak również $\mathrm{w}$ orzekaniu w tych sprawach $(\S 18,73)$ [Dz. Praw 1842, nr 3 D.K.; (Cichoń P., 2014, s.360)]. Dotyczyło to też spraw z zakresu cenzury, o ile nie były zbrodniami $[\mathrm{Na}$ mocy statutu organicznego dla władz sądowych kraju Wolnego Miasta Krakowa z 25 I 1842 r., (Dz. Praw 1842)]. Materialnoprawną podstawą działalności sądowej Dyrekcji Policji był austriacki kodeks karny cz. 2 z 1803 r. obowiązujący w Wolnym Mieście Krakowie (Austriackim kodeksem karnym z 1803 r. w Wolnym Mieście Krakowie posługiwano się w przekładzie polskim, Księga ustaw na zbrodnie i ciężkie policyine przestępstwa, cz. 1, O zbrodniach, cz. 2, Księga ustaw o ciężkich przestępstwach policyinych i o sposobie z temiż postępowania, 1804).

Według Nowej Instrukcji z 1833 r. przeciwdziałanie przestępczości wiązało się także z dozorem nad skazanymi opuszczającymi więzienia, co miało zniechęcać ich do powrotu do działalności przestępczej. W tym celu pozyskiwano informacje o planowanym miejscu zamieszkania i zatrudnienia takich osób. Innym przejawem

(C) 2018 /Published by: Międzynarodowy Instytut Innowacji Nauka-Edukacja-Rozwój w Warszawie, Polska

This is an open access article under the CC BY-NC license

(http://creativecommons.org/licenses/by-nc/4.0/)

Cichoń P. (2018). Protection of Public Order and Safety in The Legislation of The Free City of Cracow 1815-1846. International Journal of Legal Studies, 1(3)2018; 337-357

DOI 10.5604/01.3001.0012.2183 
działalności prewencyjnej była kontrola handlu obwoźnego, co miało przeciwdziałać paserstwu i drobnym kradzieżom, których dopuszczali się głównie służący oraz młodzież (art.140, 148-149) (Dz. Praw 1834, nr 2736 D.G.S.).

Warto podkreślić, że warunkiem skuteczności działań związanych z zapewnieniem porządku i bezpieczeństwa publicznego było egzekwowanie odpowiedzialności administracyjnej wobec osób, które naruszały obowiązujące w tym zakresie przepisy, dopuszczając się tym samym tzw. przestępstw policyjno-administracyjnych zwanych również lekkimi przestępstwami policyjnymi. Wysokość kar za tego rodzaju przestępstwa została określona w przepisach prawa w odniesieniu do konkretnych naruszeń prawa. Zarówno stawki pieniężne, jak również wysokość aresztu lub chłosty były zróżnicowane dla różnych czynów [Np. naruszenie przepisów Urządzenia ogniowego z 1842 r. o ile nie było traktowane jako ciężkie przestępstwo policyjne stypizowane w kodeksie karnym cz. 2, podlegało karom pieniężnym w wysokości od 2 do 200 złp, karze aresztu od 24 godzin do miesiąca lub karze cielesnej od 5 do 20 plag, stosownie do okoliczności i stopnia winy (art.82)] (Dz. Praw 1842, nr 6513 D.G.). Dotyczyło to m.in. nierzetelnego prowadzenia działalności gospodarczej, niedopełnienia obowiązku meldunkowego, naruszenia przepisów porządkowych, przeciwpożarowych, nieuczciwych praktyk handlowych, niewywiązania się z obowiązku udziału w akcji gaśniczej itd. (np. art. 207, pkt. 1-101) (Dz. Praw 1834, nr 2736 D.G.S.). Wprowadzony system sankcji administracyjnych, drobiazgowo określony, przypominający współczesne taryfikatory mandatowe, dawał szansę na podniesienie skuteczności egzekwowania prawnych obowiązków administracyjnych ciążących na różnych podmiotach. W większości wypadków były to kary pieniężne, których wysokość wzrastała w przypadku popełnienia po raz kolejny tego samego przestępstwa [Np. sprzedaż pieczywa o zaniżonej wadze lub po cenie niezgodnej z urzędowymi taksami podlegała karze pieniężnej w wysokości 6 złp (za pierwsze wykroczenie), 12 złp (za drugie), 18 złp (za trzecie). W przypadku kolejnej nielegalnej sprzedaży wszczynano postępowanie karne $\mathrm{z}$ uwagi na popełnienie ciężkiego przestępstwa policyjnego (art. 207, pkt 1). Analogiczne kary przewidziano za sprzedaż mydła lub świec niezgodnie z urzędową taksą (art. 207, pkt 19). Za produkcję i sprzedaż piwa złej jakości, jak również sprzedaż nad taksę przewidziano karę dla

(C) 2018 /Published by: Międzynarodowy Instytut Innowacji Nauka-Edukacja-Rozwój w Warszawie, Polska

This is an open access article under the CC BY-NC license

(http://creativecommons.org/licenses/by-nc/4.0/)

Cichoń P. (2018). Protection of Public Order and Safety in The Legislation of The Free City of Cracow 1815-1846. International Journal of Legal Studies, 1(3)2018; 337-357

DOI 10.5604/01.3001.0012.2183 
piwowara w wysokości $10 \mathrm{złp} \mathrm{(za} \mathrm{pierwsze} \mathrm{wykroczenie),} 20$ złp (za drugie), 50 złp (za trzecie), ] (Dz. Praw 1834, nr 2736 D.G.S.). W niektórych przypadkach karą za trzykrotne popełnienie tego samego przestępstwa był zakaz dalszego prowadzenia działalności np. handlowej lub usługowej [Np. kara za zatrudnianie kobiet w wieku poniżej 40 lat (niezależnie czy stanu wolnego czy zamężnych) w szynkach bez zezwolenia wynosiła 50 złp (za pierwsze wykroczenie), 100 złp (za drugie wykroczenie), utrata konsensu czyli pozwolenia na prowadzenie szynku (za trzecie wykroczenie). Takie same kary przewidziano za nielegalne prowadzenie szynku (art. 6c), Dz. Rządowy WMK 1829, nr 9, s. 35-36, nr 929. Za otwieranie szynków poza ustawowo określonymi godzinami czy też utrzymywanie w nich muzyki bez stosownego zezwolenia wymierzano karę w wysokości 12 złp (za pierwsze wykroczenie), 24 złp (za drugie), karę utraty konsensu (za trzecie), art. 14 pkt. 8] (Dz. Praw 1839, nr 7009 D.G.S.). Dalsze dopuszczanie się tych samych przestępstw pociągało za sobą odpowiedzialność prawną na podstawie kodeksu karnego [Np. sprzedaż węgla przy użyciu fałszywej miary (...)podlegała karze pieniężnej w wysokości 6 złp (za pierwsze wykroczenie), 18 złp (za drugie). W przypadku popełnienia tego rodzaju przestępstwa po raz trzeci, wszczynano postępowanie karne na podstawie kodeksu karnego, (art. 207, pkt 33),] (Dz. Praw 1834, nr 2736 D.G.S.). W przypadku przestępstw związanych $\mathrm{z}$ oferowaniem towarów złej jakości lub niezgodnie $\mathrm{z}$ urzędowych taksami lub towarów pochodzących z nielegalnych źródeł, stosowano karę konfiskaty [Np. art. 207, pkt. 3,4,7, 13, 40,] (Dz. Praw 1834, nr 2736 D.G.S.). Wobec cudzoziemców najsurowszą karą było wydalenie z Wolnego Miasta Krakowa [Np. karą dla cudzoziemca za nielegalne otwarcie i prowadzenie pensji dla młodzieży było wydalenie z kraju. Pozostałe osoby podlegały karze pieniężnej w wysokości od 100 do 500 złp. W przypadku powtórnego stwierdzenia prowadzenia pensji bez wymaganego zezwolenia, osoba prowadząca taką szkołę podlegała karze dożywotniego pozbawienia jej uprawnień do prowadzenia tego typu placówki (art. 2),] (Dz. Praw 1842, nr 5271 D.G.S.). Szczególne znaczenie dla egzekwowania obowiązków administracyjnych miała Nowa Instrukcja z 1833 r., która w art. 207 przewidywała 101 typów lekkich przestępstw policyjnych.

(C) 2018 /Published by: Międzynarodowy Instytut Innowacji Nauka-Edukacja-Rozwój w Warszawie, Polska

This is an open access article under the CC BY-NC license

(http://creativecommons.org/licenses/by-nc/4.0/)

Cichoń P. (2018). Protection of Public Order and Safety in The Legislation of The Free City of Cracow 1815-1846. International Journal of Legal Studies, 1(3)2018; 337-357

DOI 10.5604/01.3001.0012.2183 


\section{Podsumowanie}

Podsumowując powyższe rozważania można potwierdzić postawioną na wstępie tezę, że problematyka dotycząca ochrony porządku i bezpieczeństwa publicznego była przedmiotem regulacji licznych aktów prawnych i to różnej rangi. Charakterystyczną cechą tych aktów prawnych było wzajemne przenikanie się w nich elementów nadzoru administracyjnego nad konkretną dziedziną życia społecznego z elementami karno-administracyjnymi, związanymi z przyznaniem organom administracyjno-policyjnym uprawnień do wymierzania tego typu sankcji za naruszenie prawa. Choć występujące w tych aktach pojęcia ,porządek publiczny” i „bezpieczeństwo publiczne" były nieostre, to podlegały one konkretyzowaniu przez organy administracyjne w procesie stosowania prawa. Przepisy określały różnego typu działania, o charakterze prewencyjnym jak i represyjnym, które służyły eliminowaniu zagrożeń destabilizujących porządek, spokój i bezpieczeństwo mieszkańców Wolnego Miasta Krakowa. A zatem celem wydawania tak wielu przepisów była chęć ochrony interesów ogólnospołecznych oraz różnych aspektów związanych ze spokojnym i bezpiecznym życiem. Niektóre $\mathrm{z}$ tych zadań miało jednak swoje uzasadnienie polityczne wynikające z zależności prawnej Wolnego Miasta Krakowa od mocarstw opiekuńczych tj. Austrii, Prus i Rosji. Dotyczyło to przede wszystkim spraw związanych z korzystaniem z paszportów oraz z kontrolą ruchu ludności. Z kolei działania represyjne przybierały głównie charakter wymierzania kar za lekkie oraz ciężkie przestępstwa policyjne. Od lat trzydziestych widoczna stała się tendencja do centralizacji i koncentracji kompetencji z dziedziny utrzymania porządku i bezpieczeństwa publicznego. Większość zadań z tej dziedziny przekazywano Dyrekcji Policji, która od 1836 r. zarządzana już była przez austriackich dyrektorów, którzy oficjalnie kierowali się także wytycznymi wydawanymi przez przedstawicieli mocarstw opiekuńczych (Cichoń P., 2014, s.140). 


\section{Literatura:}

1. BARTEL W. M., (1976), Ustrój i prawo Wolnego Miasta Krakowa (1815-1846). Biblioteka Krakowska, nr 116. Kraków.

2. BIENIARZÓWNA J., MAŁECKI J.M., 1979, Kraków w latach 1796-1918. Dzieje Krakowa, t. 3, Kraków.

3. CICHOŃ P., (2012), Przyczynek do dziejów żandarmerii Wolnego Miasta Krakowa. in GRODZISKI S., DZIADZIO A. (ed.) RegnareGubernareArministrare z dziejów administracji, sądownictwa i nauki prawa, Kraków.

4. CICHOŃ P., (2014), Dyrekcja Policji Wolnego Miasta Krakowa 1827-1846. Studium historyczno-prawne. Kraków.

5. KALLAS M., KRZYMKOWSKI M., (2006), Historia ustroju i prawa $w$ Polsce 1772/1795-1918. Wybór źródeł. Warszawa.

6. NAMYSŁOWSKI W., (1913), Milicya Wolnego Miasta Krakowa1815-1846. Kraków.

7. WACHHOLZ SZ., (1957), Rzeczpospolita Krakowska. Okres od 1815 do 1830 r. Warszawa

\section{Źródla prawa:}

8. Dz. Roz. Rządowych WMK 1816, nr 2104,

9. Dz. Roz. Rządowych WMK 1817, nr 386,

10. Dz. Roz. Rządowych WMK 1822, nr 58 D.G.

11. Dz. Praw RK 1827, nr 3344 D.G.S.

12. Dz. Praw RK 1827, nr 3999,

13. Dz. Rządowy WMK 1829, nr 9,

14. Dz. Rządowy WMK 1829, nr 929,

15. Dz. Rządowy WMK 1830, nr 12-13,

16. Dz. Rządowy WMK 1830, nr 1168,

17. Dz. Rządowy WMK 1831, nr 2,

18. Dz. Rządowy WMK 1831, nr 2927 D.G.S.;

19. Dz. Roz. Rządowych WMK 1832, nr 31,

20. Dz. Rządowy WMK 1832, nr 36-37,

21. Dz. Roz. Rządowych WMK 1832, nr 5024 D.G.S.

22. Dz. Roz. Rządowych WMK 1832, nr 5918 D.S.

23. Dz. Rządowy WMK 1833, nr 13-14,

24. Dz. Rządowy WMK 1833, nr 2411 D.G.S.

25. Dz. Praw 1834, nr 2736 D.G.S.

26. Dz. Rządowym WMK 1835, nr 46-47,

27. Dz. Rządowym WMK 1835, nr 7054 D.G.S.

(C) 2018 /Published by: Międzynarodowy Instytut Innowacji Nauka-Edukacja-Rozwój w Warszawie, Polska

(ब) This is an open access article under the CC BY-NC license

(http://creativecommons.org/licenses/by-nc/4.0/)

Cichoń P. (2018). Protection of Public Order and Safety in The Legislation

of The Free City of Cracow 1815-1846. International Journal of Legal Studies, 1(3)2018; 337-357

DOI 10.5604/01.3001.0012.2183 
28. Dz. Praw 1836, nr 6299 D.G.S.

29. Dz. Praw 1836, nr 6908 D.G.S.

30. Dz. Rządowy WMK 1836, nr 11-12,

31. Dz. Rządowy WMK 1836, nr 1421 D.G.S.

32. Dz. Rządowy WMK 1837, nr 33-34,

33. Dz. Rządowy WMK 1837, nr 1095 D.G.S.

34. Dz. Rządowy WMK 1839, nr 15-16,

35. Dz. Praw 1839, nr 23.

36. Dz. Rządowy WMK 1839, nr 1167 D.G.S.

37. Dz. Praw 1839, nr 3388 D.G.S.

38. Dz. Praw 1839, nr 7009 D.G.S.

39. Dz. Praw 1840, nr 10 D.K.

40. Dz. Praw 1840, s. 1-2, nr 287 D.G.S.

41. Dz. Praw 1841, nr 1492 D.G.S.

42. Dz. Praw 1842, nr 3 D.K.

43. Dz. Praw 1842, nr 846 D.G.S.

44. Dz. Praw 1842, nr 5271 D.G.S.

45. Dz. Praw 1842, nr 6513 D.G.

46. Dz. Rządowym WMK 1842, nr 32-33,

47. Dz. Rządowym WMK 1842, nr 1408.

48. Dz. Praw 1845, nr 472 D.G.S.

49. Dz. Praw 1845, nr 915 D.G.S.

50. Archiwum Narodowe w Krakowie, WM-588, k. 4, nr 4882.

51. KSIĘGA USTAW na zbrodnie i ciężkie policyjne przestępstwa (1804), cz. 1, O zbrodniach, cz. 2, Księga ustaw o ciężkich przestępstwach policyinych i o sposobie z temiż postępowania, Kraków. Dz. Rządowy WMK 1816, przepis ten został opublikowany oddzielnie (brak numeru dziennika), nr 816. 